\title{
Native plant species richness in non-native Pinus contorta forest
}

\author{
Clayson J. Howell* and Kate G. McAlpine \\ Department of Conservation, PO Box 10-420, Wellington 6143, New Zealand \\ *Author for correspondence (Email: chowell@doc.govt.nz)
}

Published online: 28 August 2015

\begin{abstract}
Pinus contorta (lodgepole pine) is invasive in many southern hemisphere countries, having spread extensively from original plantings. It is widely controlled to limit its spread and negative impacts, and is generally assumed to have little value for native plant biodiversity. We surveyed vegetation in two stands of montane wilding $P$. contorta forest, and recorded a subcanopy of more than 50 native plant species from 35 genera, including trees, shrubs, ferns, and orchids. Canopy openness ranged between 5 and 20\% and was positively related to native plant species richness at both sites. Native plant species richness was negatively related to $P$. contorta stem density at one site but not the other, where richness was positively related to soil available phosphorus concentrations. A diverse native subcanopy in wilding $P$. contorta forest may represent an important seed source for further native regeneration in invaded areas. Pinus contorta control methods that minimise disturbance to the native subcanopy may be prudent if a return to native vegetation is a long-term management goal.
\end{abstract}

Keywords: canopy openness; Fuscospora; wilding pines

\section{Introduction}

Invasive trees are recognised as a major problem worldwide (Richardson et al. 2014). In New Zealand, freely regenerating non-native conifers are referred to as wildings (Ledgard 2003), and collectively it is estimated that they have encroached upon 1.3 million ha (Clifford et al. 2013). Of the ten species that currently cause almost all wilding conifer problems in New Zealand (Froude 2011), P. contorta is the most widespread and has been estimated to comprise as much as two-thirds of the total wilding area (Ledgard 2001). Pinus contorta predominantly invades human-induced, seral grasslands and shrublands (Ledgard 2003; Dehlin et al. 2008). It is considered an environmental weed (sensu Falk-Petersen et al. 2006) because as stands of $P$. contorta coalesce, native grass, herb and shrub species present at establishment are displaced (Ledgard \& Paul 2008).

In New Zealand, it is widely assumed that dense $P$. contorta stands have little or no value for native plant biodiversity, but, to our knowledge, this has not been investigated. Studies from North America demonstrate that shade-tolerant species can establish in (native) $P$. contorta forest in the absence of disturbance (Sullivan et al.2000), with canopy-forming species eventually replacing much of the $P$. contorta if conditions remain suitable (Habeck 1968; Kobe \& Coates 1997). Additionally, $P$. contorta establishment within closed canopy P. contorta is rare (Johnson et al. 1994), as seedlings require at least $40 \%$ full sunlight to grow (Lotan \& Perry 1983), and saplings do not persist below $25 \%$ full sunlight (Claveau et al. 2002). This suggests that in New Zealand, where native seed sources are available, there is potential for native plant species to persist in or colonise the understorey of $P$. contorta forests, thus representing native biodiversity values. In this study, we set out to describe vegetation beneath $P$. contorta prior to a manipulative experiment investigating native plant responses to $P$. contorta control.

\section{Methods}

This study was established in April 2011, in two large stands ('Black Birch' and 'Don Juan') of wilding P. contorta in the Kaweka Forest Park, North Island, New Zealand. The Black Birch site $\left(39.30^{\circ} \mathrm{S}, 176.44^{\circ} \mathrm{E}\right)$ was located between 1040 and $1080 \mathrm{~m}$ a.s.l. on the Black Birch ridge, to the north of Trig A8A8. The Don Juan site $\left(39.34^{\circ} \mathrm{S}, 176.47^{\circ} \mathrm{E}\right)$ was located between 880 and $940 \mathrm{~m}$ a.s.l., to the north of Trig A3R0. Pinus contorta began to spread at these sites in the 1960 s following establishment trials designed to reduce soil erosion (Cunningham \& Roberts 1970). Remaining native montane (sensu Wardle 1991) forests in this area are dominated by mountain beech (Fuscospora cliffortioides) and red beech (F.fusca) with occasional podocarp species, including mountain tōtara (Podocarpus cunninghamii), and mountain toatoa (Phyllocladus alpinus). Extensive tracts ( $>5$ ha) of native forest occur within $400 \mathrm{~m}$ of both sites, and smaller patches $(<1 \mathrm{ha})$ of native trees and shrubs are scattered throughout. The pattern of distribution of these species reflects the highly modified nature of the area after several hundred years of sporadic burning (Rogers 1994) and attempted conversion to grazing (Elder 1941).

Twelve locations were established in 7-14 m-high $P$. contorta forest at both sites. At each location, a patch of trees $30 \mathrm{~m}$ in diameter was marked out, giving a total of 24 patches. Each patch was a minimum of $20 \mathrm{~m}$ from any forest edge or tree fall gap, and a minimum of $20 \mathrm{~m}$ from any other patch. Four $2 \times 2 \mathrm{~m}$ plots were established in each patch, $2 \mathrm{~m}$ from the patch centre on north, east, south and west bearings, giving a total of 96 plots. In the $2 \times 2$ m plots, vegetation was assessed according to the Recce method (Hurst \& Allen 2007). Species were assessed individually, and each plot was also scored for overall native vegetation cover. Seedlings were generally only included if they were beyond the cotyledon stage. However, $P$. contorta seedlings at the cotyledon stage were included, because they were easily identifiable and their 
presence, even if ephemeral, was germane to our study. For each plot the number of native species (native richness) was calculated.

Canopy openness was used as an index of light availability. To measure this we took photographs of the forest canopy from approximately $1 \mathrm{~m}$ above the middle of each plot using a digital SLR camera (Canon EOS 50D, Canon Inc.) and $4.5 \mathrm{~mm}$ hemispherical (fisheye) lens (Sigma EX DC, Sigma Corporation of America, New York, USA). Photographs were then digitally analysed using the HemiView image processing software (HemiView Forest Canopy Analysis System v8, Delta-T Devices, Cambridge, UK).

All $P$. contorta stems within a 5-m radius of the patch centre were counted (stem density) and their dbh (diameter at breast height of $1.3 \mathrm{~m}$ ) was measured. Within the 5-m radius, 10 soil samples were taken in a ' $Z$ ' pattern. Surface litter was excluded and samples were taken from the top $10 \mathrm{~cm}$ of soil using a $2.5 \mathrm{~cm}$ diameter soil corer. Patch samples were pooled and analysed by R.J. Hill Laboratories Limited for the organic carbon, total nitrogen, carbon to nitrogen ratio $(\mathrm{C}: \mathrm{N})$ and available phosphorus (Olsen $\mathrm{P}$ ) concentrations using standard tests. We compared soil characteristics of the two sites using Welch two sample t-tests in statistical software package ' $R$ ' (version 2.15.3) (R Core Team 2013).

We used the package 'Ime4' (Bates et al. 2012) in ' $R$ ' for analyses. We used mixed effects models with Poisson error structures to model the response of native species richness to factors we considered most likely to be important. Plot and patch were included as nested random effects to account for spatial clustering. Other covariates assessed for inclusion in the model were dbh, canopy openness, stems per ha, $\mathrm{C}: \mathrm{N}$ ratio and Olsen P. Akaike's Information Criterion (AICc) was used to rank models (package 'AICmodavg') (Mazerolle 2013) within each site, with the lowest AICc ranked first. We calculated the evidence ratio between first and second ranked models, the marginal and conditional $R^{2}$ (Nakagawa \& Schielzeth 2013) and weight of the highest ranked model, and the ranking of the null model including only the random effects.

\section{Results}

A total of 49 species, from 35 native plant genera, was recorded (Table 1). More than half (55\%) of the native species were woody trees or shrubs, $20 \%$ were ground ferns, and the remaining $25 \%$ were herbs, orchids, grasses, and vines. Native plants were predominantly found in lower tiers, but 12 plots contained some native cover greater than $2 \mathrm{~m}$ tall (Table 1). Griselinia littoralis and Gaultheria antipoda were common at both sites but some species common at Black Birch were rare or absent at Don Juan (e.g. Coprosma dumosa, Phyllocladus alpinus) and vice versa (e.g. C. grandifolia). Beech species were found in six plots, but all were less than $1 \mathrm{~m}$ tall.

Pinus contorta was the dominant component of the vegetation, but saplings and seedlings of $P$. contorta were scarce, with only four seedlings recorded, all of which were at the cotyledon stage (Fig. 1). Pinus contorta stem density ranged from 2299 to 15915 live stems per ha and average dbh ranged from 11.5 to $32.9 \mathrm{~cm}$ per patch. Counting annual rings on a subset of these trees that were later felled suggested typical ages of between 30 and 40 years. Canopy openness was variable, and ranged from 5.0 to $20 \%$ (Fig. 2). The most open sites were those with small mean diameter $P$. contorta (Fig. 2). The soils beneath the two sites varied significantly: soils from Don Juan had much greater available phosphorus, but contained less organic carbon and total nitrogen than those at Black Birch (Table 2).

The density of $P$. contorta stems, extent of canopy openness, and their interaction were important predictors of native species richness at Black Birch, with the greatest richness found under relatively widely-spaced trees with open canopies (Table 3 ). The best model (stems per ha, canopy openness and their interaction) had a marginal $R^{2}$ of 0.52 , conditional $R^{2}$ of 0.54 and was 96 times more likely than the second-ranked model to be the best model in the candidate set (Table 2). At Don Juan, the greatest native species richness was associated with high levels of Olsen $\mathrm{P}$ under open canopies. The best model (canopy openness and Olsen P) had a marginal $R^{2}$ of (a) native species

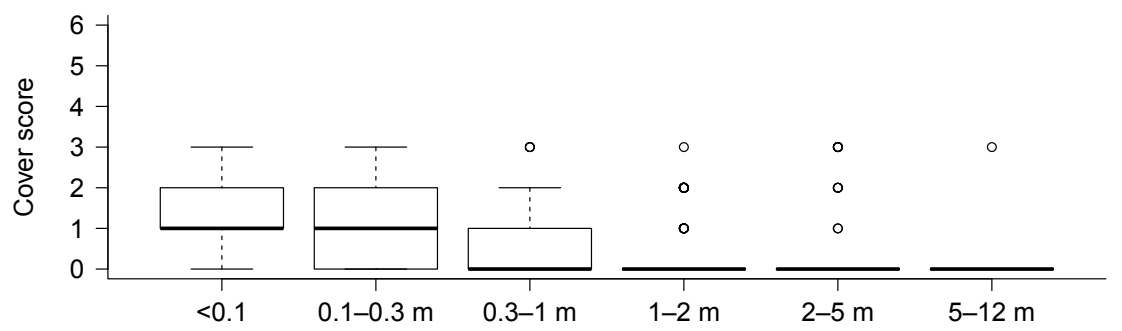

(b) Pinus contorta

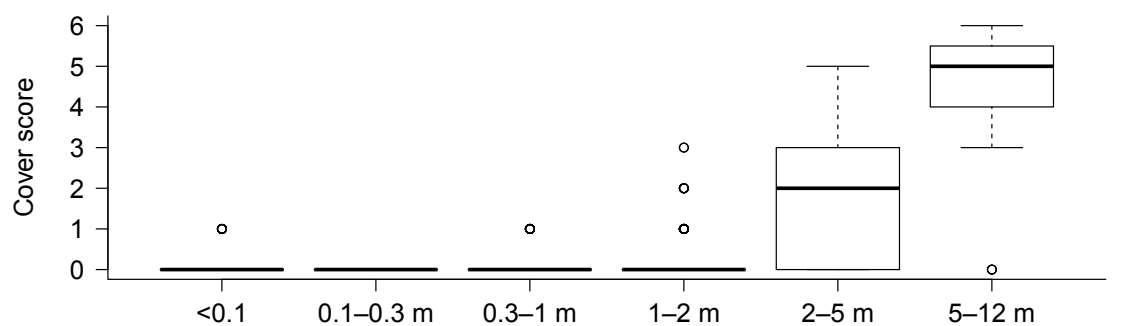

Figure 1. Cover of (a) native species combined and (b) Pinus contorta. Each box plot represents the average cover score by height tier across all plots. Cover scores represent $\%$ cover of live foliage in each height tier: $1=<1 \%, 2=$ $1-5 \%, 3=6-25 \%, 4=26-50 \%, 5=51-75 \%$, $6=76-100 \%$. 
Table 1. Plant species recorded in Pinus contorta forest. Values indicate the number of plots (out of a potential 96) in which each species was recorded, both overall (Total plots) and for each site (Black Birch and Don Juan) separately. Bracketed values are number of plots where plants were recorded in tiers above $2 \mathrm{~m}$.

\begin{tabular}{llccc} 
& & & \multicolumn{2}{c}{ Number of plots per site } \\
\cline { 4 - 5 } Growth form & Species & Total plots & Black Birch & Don Juan \\
& & & & \\
& Carpodetus serratus & 2 & 0 & 2 \\
& Coprosma grandifolia & 31 & 6 & $25(1)$ \\
& Coprosma robusta & 11 & 1 & $10(1)$ \\
& Fuscospora cliffortioides & 1 & 1 & 0 \\
& Fuscospora fusca & 5 & 2 & 3 \\
& Griselinia littoralis & 27 & 15 & 12 \\
& Leptospermum scoparium & 10 & $6(4)$ & $4(2)$ \\
& Phyllocladus alpinus & 20 & $20(2)$ & 0 \\
& Pinus contorta* & 96 & $48(48)$ & $48(48)$ \\
& Podocarpus cunninghamii & 4 & 4 & 0 \\
& Pseudopanax colensoi & 13 & 13 & 0
\end{tabular}

shrubs

$\begin{array}{lccc}\text { Coprosma colensoi } & 1 & 1 & 0 \\ \text { Coprosma dumosa } & 42 & 40 & 2 \\ \text { Coprosma foetidissima } & 3 & 3 & 0 \\ \text { Coprosma linariifolia } & 8 & 8 & 0 \\ \text { Coprosma microcarpa } & 1 & 1 & 0 \\ \text { Coprosma propinqua } & 6 & 6 & 0 \\ \text { Coriaria arborea } & 2 & 0 & 2(2) \\ \text { Gaultheria antipoda } & 23 & 10 & 13 \\ \text { Gaultheria depressa } & 1 & 1 & 0 \\ \text { Helichrysum lanceolatum } & 2 & 1 & 1 \\ \text { Leptecophylla juniperina } & 12 & 6 & 6 \\ \text { Leucopogon fasciculatus } & 6 & 6 & 0 \\ \text { Leucopogon fraseri } & 1 & 1 & 0 \\ \text { Lupinus arboreus* } & 4 & 0 & 4 \\ \text { Myrsine divaricata } & 11 & 11 & 0 \\ \text { Olearia arborescens } & 15 & 2 & 13 \\ \text { Olearia nummulariifolia } & 2 & 2 & 0 \\ \text { Pseudowintera colorata } & 5 & 5 & 0\end{array}$

lianas

$\begin{array}{llll}\text { Clematis sp. } & 4 & 1 & 3\end{array}$

dicot herbs

Celmisia spectabilis $\times$ gracilenta

Lagenophora strangulata

Nertera ciliata

Nertera villosa

Ranunculus reflexus

monocot herbs

Astelia fragrans
Chiloglottis cornuta
Phormium cookianum
Pterostylis sp.
Uncinia sp.

$\begin{array}{ccc}6 & 6 & 0 \\ 10 & 10 & 0 \\ 5 & 5 & 0 \\ 1 & 1 & 0 \\ 1 & 1 & 0\end{array}$

grasses

ferns

Asplenium flaccidum
Blechnum discolor
Blechnum fluviatile
Blechnum penna-marina
Blechnum procerum
Hymenophyllum flabellatum
Microsorum pustulatum
Notogrammitis billardierei
Polystichum vestitum
Pyrrosia eleagnifolia

$\begin{array}{lll}5 & 0 & 5 \\ 1 & 0 & 1 \\ 1 & 1 & 0 \\ 5 & 1 & 4 \\ 5 & 1 & 4 \\ 8 & 5 & 3 \\ 7 & 0 & 7 \\ 5 & 0 & 5 \\ 1 & 0 & 1 \\ 1 & 0 & 1\end{array}$

\footnotetext{
*non-native species
} 


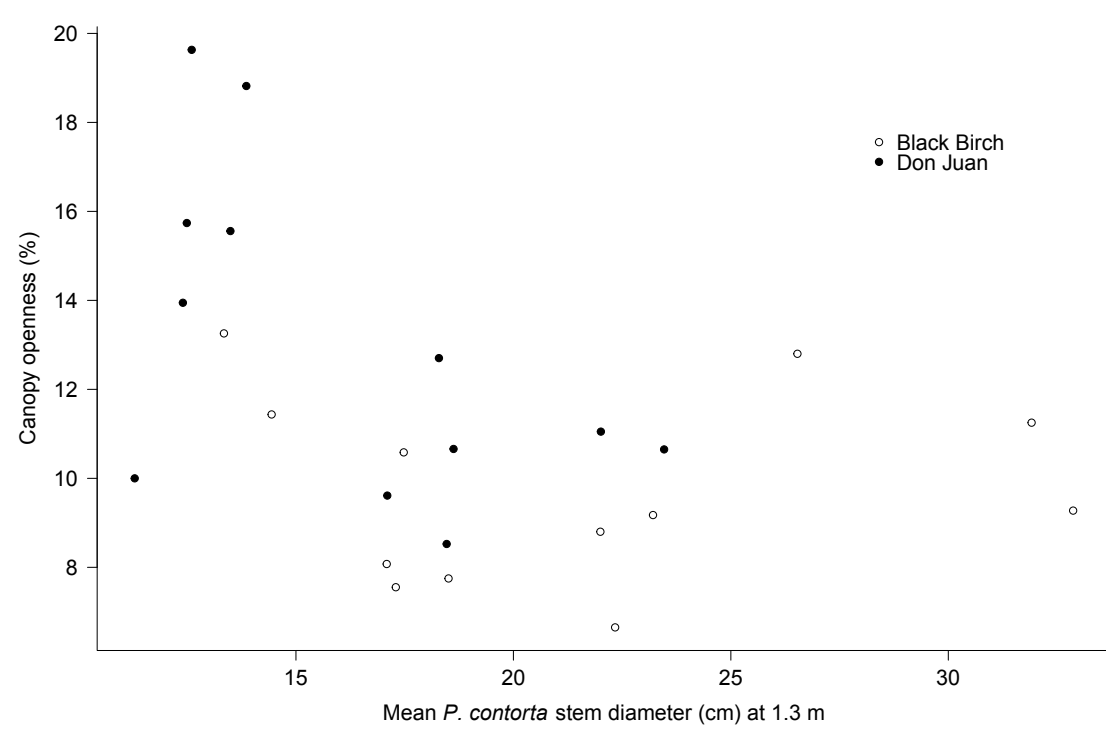

Figure 2. Canopy openness (\%) and mean $P$. contorta stem diameter at 24 patches in the Kaweka Forest Park.

Table 2. Estimates of mean (and standard error) of soil parameters and significance resulting from Welch two-sample $t$ test to investigate differences between sites.

\begin{tabular}{llllll}
\hline & Black Birch & Don Juan & $t$ & df & $P$ \\
\hline Olsen P $\left(\mathrm{mg} \mathrm{kg}^{-1}\right)$ & $0.85(0.046)$ & $3.36(0.267)$ & -4.47 & 11.64 & 0.0008 \\
Organic C (\%) & $4.09(0.215)$ & $2.31(0.088)$ & 3.68 & 14.59 & 0.0023 \\
Total N $(\%)$ & $0.16(0.007)$ & $0.08(0.002$ & 5.09 & 13.14 & 0.0002 \\
C:N ratio & $25.17(0.397)$ & $28.97(0.764)$ & -2.14 & 16.53 & 0.0480 \\
\hline
\end{tabular}

Table 3. Candidate models for predictors of native species richness under Pinus contorta canopy at Black Birch and Don Juan sites. Openness $=$ canopy openness, Stems $=$ stems ha ${ }^{-1}$. Models are ranked on $\mathrm{AIC}_{\mathrm{c}}$ (Akaike Information Criterion adjusted for small sample size). $k=$ number of parameters, $\Delta \mathrm{AIC}_{\mathrm{c}}$ shows $\mathrm{AIC}_{\mathrm{c}}$ relative to the best model, $\mathrm{AIC}{ }_{\mathrm{c}} w_{i}$ shows the weight (relative strength) of support for each model, Cum. $w$ indicates cumulative weight of models in the candidate set, $\mathrm{LL}=\log$ likelihood.

\section{Black Birch}

\begin{tabular}{|c|c|c|c|c|c|c|}
\hline Models of native species richness & $k$ & $\mathrm{AIC}_{\mathrm{c}}$ & $\Delta \mathrm{AIC}_{\mathrm{c}}$ & $w_{i}$ & Cum. $w$ & $\mathrm{LL}$ \\
\hline Stems + Openness + Stems $\times$ Openness & 7 & 76.798 & 0.000 & 0.966 & 0.966 & -29.999 \\
\hline $\mathrm{dbh}+$ Openness & 6 & 85.925 & 9.128 & 0.010 & 0.976 & -35.938 \\
\hline Openness & 5 & 86.471 & 9.673 & 0.008 & 0.984 & -37.521 \\
\hline $\mathrm{dbh}+$ Openness $+\mathrm{dbh} \times$ Openness & 7 & 87.086 & 10.288 & 0.006 & 0.989 & -35.143 \\
\hline Stems + Openness & 6 & 87.639 & 10.841 & 0.004 & 0.993 & -36.795 \\
\hline Openness $+\mathrm{C}: \mathrm{N}$ & 6 & 88.233 & 11.435 & 0.003 & 0.997 & -37.092 \\
\hline Openness + Olsen P & 6 & 88.589 & 11.791 & 0.003 & 0.999 & -37.270 \\
\hline $\mathrm{dbh}$ & 5 & 93.480 & 16.682 & 0.000 & 0.999 & -41.026 \\
\hline Null model (random effects only) & 4 & 93.502 & 16.704 & 0.000 & 1.000 & -42.286 \\
\hline $\mathrm{dbh}+\mathrm{C}: \mathrm{N}$ & 6 & 94.643 & 17.845 & 0.000 & 1.000 & -40.297 \\
\hline Stems & 5 & 94.847 & 18.049 & 0.000 & 1.000 & -41.709 \\
\hline Stems $+C: N$ & 6 & 96.690 & 19.892 & 0.000 & 1.000 & -41.321 \\
\hline \multicolumn{7}{|l|}{ Don Juan } \\
\hline Models of native species richness & $k$ & $\mathrm{AIC}_{\mathrm{c}}$ & $\Delta \mathrm{AIC}_{\mathrm{c}}$ & $w_{i}$ & Cum. $w$ & LL \\
\hline Openness + Olsen P & 6 & 81.387 & 0.000 & 0.850 & 0.850 & -33.669 \\
\hline Openness & 5 & 87.514 & 6.127 & 0.040 & 0.890 & -38.043 \\
\hline Openness $+\mathrm{C}: \mathrm{N}$ & 6 & 88.014 & 6.627 & 0.031 & 0.921 & -36.982 \\
\hline $\mathrm{dbh}+$ Openness & 6 & 88.026 & 6.639 & 0.031 & 0.951 & -36.988 \\
\hline Stems + Openness & 6 & 88.842 & 7.456 & 0.020 & 0.972 & -37.397 \\
\hline $\mathrm{dbh}+$ Openness $+\mathrm{dbh} \times$ Openness & 7 & 90.312 & 8.925 & 0.010 & 0.982 & -36.756 \\
\hline $\mathrm{dbh}$ & 5 & 90.496 & 9.109 & 0.009 & 0.991 & -39.534 \\
\hline Stems + Openness + Stems $\times$ Openness & 7 & 91.580 & 10.194 & 0.005 & 0.996 & -37.390 \\
\hline $\mathrm{dbh}+\mathrm{C}: \mathrm{N}$ & 6 & 92.983 & 11.596 & 0.003 & 0.998 & -39.467 \\
\hline Null model (random effects only) & 4 & 95.537 & 14.151 & 0.001 & 0.999 & -43.304 \\
\hline Stems $+C: N$ & 6 & 96.183 & 14.796 & 0.001 & 1.000 & -41.067 \\
\hline Stems & 5 & 97.006 & 15.619 & 0.000 & 1.000 & -42.789 \\
\hline
\end{tabular}


0.37 , conditional $R^{2}$ of 0.41 and was 21.4 times more likely than the second ranked model to be the best model in the candidate set.

\section{Discussion}

We found a diverse assemblage of native species beneath the $P$. contorta canopy, including orchids, ferns, shrubs and trees. Some differences in the species present at each site could be due to differences in altitude, e.g. Coprosma grandifolia was detected at the lower altitude site only. Given that this is a point-in-time study, we cannot determine whether commonly occurring native plant species have persisted through or colonised during $P$. contorta establishment, but it seems likely that both scenarios have occurred. Leptospermum scoparium above $2 \mathrm{~m}$ have probably persisted since $P$. contorta establishment, numerous dead $L$. scoparium stems suggests that in some plots this species was formerly more abundant. Conversely, the presence of seedlings and small saplings $(<2 \mathrm{~m}$ tall) of Fuscospora fusca, Griselinia littoralis and Phyllocladus alpinus strongly suggest that they are much younger than the $P$. contorta canopy and that there is at least some potential for native species to colonise wilding $P$. contorta forests in New Zealand.

Despite abundant seed, $P$. contorta seedlings and saplings were almost completely absent in this study. This is consistent with previous findings that $P$. contorta is unable to regenerate beneath a closed canopy (Johnson et al. 1994). As we observed several cotyledon stage seedlings, it appears that seeds can germinate under a closed canopy, but seedlings fail to establish.

Our results demonstrate a positive correlation between $P$. contorta canopy openness and native species richness at both sites. However, it is difficult to establish whether this is the result of increasing canopy openness as stands age, incomplete canopy closure, or both. Canopy closure of $P$. contorta in Wyoming, U.S.A., typically peaks at 40 to 45 years; canopies then slowly become more open over the next 80 years (Long \& Smith 1992). As $P$. contorta stands age, they tend to become more structurally complex, with greater variability of canopy cover (Sampson \& Smith 1993). Several studies of the understory in $P$. radiata plantation forests in New Zealand have demonstrated a positive correlation between native plant species richness and stand age (Allen et al. 1995; Ogden et al. 1997; Brockerhoff et al. 2003), and it has been suggested that this can be partly attributed to a more favourable light environment in older stands (Brockerhoff et al. 2008). In our study, native species richness was highest under widely-spaced trees with open canopies at the Black Birch site. However, at Don Juan the highest levels of canopy openness were associated with small diameter $P$. contorta, which suggests incomplete canopy closure. The trees in our study are still relatively young; $P$. contorta can live for at least 350 years (Smithwick et al. 2005). It is unclear if the canopy of wilding $P$. contorta stands in New Zealand will become more open as stands age beyond 40 years, but this seems likely.

The reasons behind the much higher available phosphorus concentrations in soils at Don Juan remain unclear, but it is an important predictor of native plant diversity at this site. High levels of available phosphorus may have resulted from physical processes or biotic processes related to the encroachment of P. contorta (Dickie et al. 2014) or both.

Pinus contorta is one of the most light-demanding conifers (Coates 2000). It is generally regarded as a pioneer species
(Long \& Smith 1990) and can be gradually replaced by more shade tolerant forest species in its native range (Habeck 1968). Our results demonstrate that native species can survive in $P$. contorta forest in New Zealand, but it is unclear whether they could eventually replace the $P$. contorta. Beech seedlings can survive deep shading (Wardle 1970) and are certainly more shade tolerant than $P$. contorta. Planted beech seedlings can survive beneath $P$. contorta canopy (Dehlin et al. 2008) and beech saplings up to $3 \mathrm{~m}$ tall have been observed in 60 -yearold $P$. contorta stands (Ledgard \& Paul 2008). However, the presence and possibly greater shade tolerance of some native species is no guarantee that they will eventually dominate; under certain conditions, establishment of other species under $P$. contorta canopies may be insignificant until after 200 years (Johnson et al. 1994) or not occur at all (Despain 1983). It may be possible to facilitate establishment of beech and other native species in $P$. contorta stands, for example by sowing seed, or controlling $P$. contorta in a way that promotes native seedling establishment but inhibits $P$. contorta establishment. Future research will address these possibilities.

\section{Acknowledgements}

This project was funded by the Department of Conservation (Investigation 4155). Comments from James Griffiths, Susan Timmins, Peter Bellingham and two anonymous referees improved the manuscript. Debra Wotton gave helpful statistical advice, and Helen Armstrong, James Griffiths and Jon Terry assisted with fieldwork.

\section{References}

Allen RB, Platt KH, Coker REJ 1995. Understorey species composition patterns in a Pinus radiata plantation on the central North Island volcanic plateau, New Zealand. New Zealand Journal of Forestry Science 25: 301-317.

Bates D, Maechler M, Bolker B 2012. lme4: Linear mixedeffects models using $\mathrm{S} 4$ classes. $\mathrm{R}$ package version 0.999999-0.

BrockerhoffEG, Ecroyd CE, LeckieAC, Kimberley MO 2003. Diversity and succession of adventive and indigenous vascular understorey plants in Pinus radiata plantation forests in New Zealand. Forest Ecology and Management 185: 307-326.

Brockerhoff EG, Jactel H, Parrotta JA, Quine CP, Sayer J 2008. Plantation forests and biodiversity: oxymoron or opportunity? Biodiversity and Conservation 17: 925-951.

Claveau Y, Messier C, Comeau PG, Coates KD 2002. Growth and crown morphological responses of boreal conifer seedlings and saplings with contrasting shade tolerance to a gradient of light and height. Canadian Journal of Forest Research 32: 458-468.

Clifford V, Paul T, Pearce G 2013. Quantifying the change in high country fire hazard from wilding trees. Report prepared for the New Zealand Fire Service Commission Contestable Research Fund. Rotorua, New Zealand Forest Research Institute Limited (Trading as SCION). 65 p.

Coates KD 2000. Conifer seedling response to northern temperate forest gaps. Forest Ecology and Management 127: 249-269.

Cunningham A, Roberts QA 1970. A provenance trial of Pinus cortorta at 4,800 ft. in the Kaweka Range(Assessment after 
seven years). New Zealand Journal of Forestry 15: 79-87.

Dehlin H, Peltzer DA, Allison VJ, Yeates GW, Nilsson M, Wardle DA 2008. Tree seedling performance and belowground properties in stands of invasive and native tree species. New Zealand Journal of Ecology 32: 67-79.

Despain DG 1983. Nonpyrogenous climax lodgepole pine communities in Yellowstone National Park. Ecology 64: 231-234.

Dickie IA, St John MG, Yeates GW, Morse CW, Bonner KI, Orwin K, Peltzer DA 2014. Belowground legacies of Pinus contorta invasion and removal result in multiple mechanisms of invasional meltdown. AoB plants 6: 1-15.

Elder NL 1941. Nothofagus regeneration in the Kaweka Range. New Zealand Journal of Forestry 4: 324-327.

Falk-Petersen J, Bøhn T, Sandlund OT 2006. On the numerous concepts in invasion biology. Biological Invasions 8: 1409-1424.

Froude VA 2011. Wilding conifers in New Zealand: status report. Report prepared for the Ministry of Agriculture and Forestry. Pacific Eco-Logic, Bay of Islands. 207 p.

Habeck JR 1968. Forest succession in the Glacier Park cedarhemlock forests. Ecology 49: 872-880.

Hurst JM, Allen RB 2007. The recce method for describing New Zealand vegetation - expanded manual: version 4 . Lincoln, Landcare Research. 62 p.

Johnson EA, Miyanishi K, Kleb H 1994. The hazards of interpretation of static age structures as shown by stand reconstructions in a Pinus contorta-Picea engelmannii forest. Journal of Ecology: 923-931.

Kobe RK, Coates KD 1997. Models of sapling mortality as a function of growth to characterize interspecific variation in shade tolerance of eight tree species of northwestern British Columbia. Canadian Journal of Forest Research 27: 227-236.

Ledgard N, Paul TSH 2008. Vegetation successions over 30 years of high country grassland invasion by Pinus contorta. New Zealand Plant Protection 61: 98-104.

Ledgard NJ 2001. The spread of lodgepole pine (Pinus contorta, Dougl.) in New Zealand. Forest Ecology and Management 141: 43-57.

Ledgard NJ 2003. Wilding conifers-New Zealand history and research background. In: Hill RL, Zydenbos SM, Bezar $\mathrm{CM}$ eds Managing wilding conifers in New Zealand: present and future. Proceedings of a workshop held in conjunction with the annual conference of the New Zealand Plant Protection Society. New Zealand Plant Protection Society, Christchurch, New Zealand. Pp. 1-25.

Editorial board member: Peter Bellingham

Received 13 August 2014; accepted 2 April 2015
Long JN, Smith FW 1990. Determinants of stemwood production in Pinus contorta var. latifolia forests: the influence of site quality and stand structure. Journal of Applied Ecology 27: 84--856.

Long JN, Smith FW 1992. Volume increment in Pinus contorta var. latifolia: the influence of stand development and crown dynamics. Forest Ecology and Management 53: 53-64.

Lotan JE, Perry DA 1983. Ecology and regeneration of lodgepole pine. Washington, DC, US Department of Agriculture, Forest Service. 51 p.

Mazerolle M 2013. AICcmodavg: model selection and multimodel inference based on (Q) AICC. R package ver. 1.27.

Nakagawa S, Schielzeth H 2013. A general and simple method for obtaining $R^{2}$ from generalized linear mixed-effects models. Methods in Ecology and Evolution 4: 133-142.

Ogden J, Braggins J, Stretton K, Anderson S 1997. Plant species richness under Pinus radiata stands on the central North Island volcanic plateau, New Zealand. New Zealand Journal of Ecology 21: 17-29.

R Core Team 2013. R: A language and environment for statistical computing. Vienna, Austria, R Foundation for Statistical Computing.

Richardson DM, Hui C, Nuñez MA, Pauchard A 2014. Tree invasions: patterns, processes, challenges and opportunities. Biological Invasions 16: 473-481.

Rogers GM 1994. North Island seral tussock grasslands 1. Origins and land-use history. New Zealand Journal of Botany 32: 271-286.

Sampson DA, Smith FW 1993. Influence of canopy architecture on light penetration in lodgepole pine Pinus contorta var. latifolia forests. Agricultural and Forest Meteorology 64: 63-79.

Smithwick EA, Turner MG, Metzger KL, Balser TC 2005. Variation in $\mathrm{NH} 4+$ mineralization and microbial communities with stand age in lodgepole pine (Pinus contorta) forests, Yellowstone National Park (USA). Soil Biology and Biochemistry 37: 1546-1559.

Sullivan TP, Sullivan DS, Lindgren PMF 2000. Small mammals and stand structure in young pine, seed-tree, and oldgrowth forest, southwest Canada. Ecological Applications 10: $1367-1383$.

Wardle J 1970. The ecology of Nothofagus solandri: 3. Regeneration. New Zealand Journal of Botany 8: 571-608.

Wardle P 1991. Vegetation of New Zealand. Cambridge, Cambridge University Press. 672 p. 